\title{
Flowering, Ethylene Production, and Ion Leakage of Coffee in Response to Water Stress and Gibberellic Acid
}

\author{
Ursula K. Schuch ${ }^{1}$ and Leslie H. Fuchigami \\ Department of Horticulture, Oregon State University, Corvallis, OR 97331 \\ Mike A. Nagao \\ Hawaii Agricultural Experiment Station, University of Hawaii, 461 W. Lanikaula St., Hilo, \\ HI 96720
}

\begin{abstract}
Additional index words Coffea arabica, flower-bud dormancy
Abstract. The effects of water stress and GA, on breaking dormancy of flower buds of coffee (Coffea arabica L.) were investigated. In the first experiment, water was withheld until the trees reached leaf water potentials (WP) of $-1.20,-1.75,-2.65$, or $-\mathbf{3 . 5 0}$ MPa. Water potential, ethylene production, and ion leakage of flower buds and leaf disks were examined from release from water stress until anthesis. Trees that had experienced leaf WP of less than - 2.65 MPa, and flower bud WP of about - 4.0 MPa flowered within 9 days after irrigation. In flower buds where dormancy had been broken with water stress, ethylene production was low compared to dormant buds and flowers at anthesis. In the second experiment, $0,50,100$, or $200 \mathrm{mg} \mathrm{GA}_{3}$ /liter was painted on branches of nonstressed trees. In experiment three, water was withheld until plants reached leaf WP of $-\mathbf{0 . 6},-1.3,-2.1$, or $-3.0 \mathrm{MPa}$, then two branches per tree were painted with 0,50 , and $100 \mathrm{mg} \mathrm{GA} /$ liter. Gibberellic acid partially compensated for insufficient water stress to initiate flower opening. Ethylene evolution of flower buds was affected by water stress but not by $\mathrm{GA}_{3}$ treatment. Severe water stress treatments and GA, treatment $\left(200 \mathrm{mg}^{-1 i t e r}{ }^{-1}\right)$ increased ethylene evolution of leaf disks. Ion leakage of flower buds and leaf disks was increased by severe water stress. Ion leakage of flower buds was highest at anthesis. After water stress, dormant and nondormant flower buds at the 4-mm stage could be distinguished based on their ethylene evolution. Chemical name used: gibberellic acid $\left(\mathbf{G A}_{3}\right)$.
\end{abstract}

Based on its flowering pattern, coffee is classified as a gregarious species, with individual plants flowering simultaneously over extended areas and within a short time (Cannell, 1985). Coffee flower buds become dormant after reaching 4 to $6 \mathrm{~mm}$ in length (Mes, 1957). Water stress breaks dormancy and is considered mandatory for normal flower development (Alvim, 1960; Piringer and Borthwick, 1955). After dormancy is broken, irrigation or exogenous $\mathrm{GA}_{3}$ is required to stimulate development of the flower buds to anthesis within 8 to 12 days (Alvim, 1958; Browning, 1975; van der Veen, 1968). Once nondormant flower buds respond to the growth stimulus by starting to elongate, they are committed to flower, whereas dormant buds will remain at the 4- to 6-mm stage. Dormant and nondormant buds cannot be distinguished by morphology or anatomy until 3 to 4 days after irrigation when nondormant flower buds begin to elongate (Mes, 1957).

Magalhaes and Angelocci (1976) found that dormancy was broken and flowering induced when coffee plants were subjected to water stress with a threshold leaf WP of $-1.2 \mathrm{MPa}$ or less. Water movement into a flower bud occurs with increasing water stress and is enhanced by the presence of a leaf subtending the flower bud, compared to defoliated nodes (Astegiano et al., 1988).

Environmental conditions or chemical agents that produce near lethal stress can break bud dormancy in temperate woody

\footnotetext{
Received for publication 17 Dec. 1990. Accepted for publication 11 July 1991. Oregon" Agricultural Experiment Station Technical paper no. 9611. This research was supported in part by the U.S. Dept. of Agriculture under CSRS Special Grant no. 88-34135-3604, managed by the Pacific Basin Advisory Group (PBAG). We thank D. Zobel for the use of the thermocouple psychrometer. The cost of publishing this paper was defrayed in part by the payment of page charges. Under postal regulations, this paper therefore must be hereby marked advertisement solely to indicate this fact.

'Current address: Dept. of Botany and Plant Sciences, Univ. of California, Riverside, CA 92521-0214.
}

plants (Fuchigami and Nee, 1987). Increased ion leakage and ethylene production are related to the degree of stress and breaking of dormaney in crabapple (Malus floribunda Sieb) and redosier dogwood (Cornus stolinifera Michx.) (Nee, 1986). An increase in ethylene production with increasing water loss was observed in plum leaves (Prunus insititia L.) (Kobayashi et al., 1981). Increased ion leakage coincided with peak ethylene production in freeze-damaged rhododendron leaf disks, suggesting the onset of membrane disintegration (Harber and Fuchigami, 1986).

In a previous field study we found that buds at the 4-mm stage treated with $100 \mathrm{mg} \mathrm{GA}_{3} /$ liter flowered in the absence of rain (Schuch et al., 1990). Exposure to water stress in the field could not be controlled and was not monitored. Therefore, we were unable to separate effects of water stress and $\mathrm{GA}_{3}$. The first objective of the current study was to use controlled environments to determine the effects of water stress and $\mathrm{GA}_{3}$, individually and in combination, on coffee flower bud development. Secondly, we investigated how ethylene evolution and ion leakage of flower buds and leaf tissues were affected by treatments that break dormancy.

\section{Materials and Methods}

Coffee (CV. Guatemala) trees were grown from seed in 4liter plastic pots in a mixture of 2 pumice : 1 peat : 1 soil (by volume) for 2 years in a greenhouse under $25 / 19 \mathrm{C}$ day/night cycles and natural photoperiod (Corvallis, Ore., $44^{\circ} \mathrm{N}$ latitude). Plants with flower buds $\leq 4 \mathrm{~mm}$ long were transferred to a growth chamber with an 8 -h photoperiod $\left(600 \mu \mathrm{mol} \cdot \mathrm{m}^{-2} \cdot \mathrm{s}^{-1}\right)$, $26 / 23$ ( \pm 2 ) C day/night, $60 \%$ to $80 \%$ relative humidity and were acclimated for 3 weeks before the experiments were started. Plants were irrigated every other day.

Abbreviation: WP, water potential. 
Water potential (Expt. I). Water was withheld from 4 Oct. 1989 until the leaf WP of three trees each averaged - 1.20, $-1.75,-2.65$, or $-3.50( \pm 0.2) \mathrm{MPa}$. When the desired WP were attained (day 0), plants were watered to container capacity, and thereafter, the pots were irrigated daily with $500 \mathrm{ml}$ of water. Each water-stress treatment was applied to three trees in a completely randomized design. Ten nodes per tree, tagged at the beginning of the experiment, were monitored for anthesis. The criteria for anthesis was a minimum of two open flowers per node, at least one in each leaf axil. Leaf and flower bud WP, ethylene evolution, and ion leakage were determined on day $\mathrm{O}$ before irrigation of the water-stressed plants, and 3,6, and 9 days after irrigation to release water stress. Leaf WP was determined from two leaves of each tree. Twenty flower buds were randomly collected from the three trees of each leaf WP treatment, 10 buds each were used to determine flower-bud WP and ethylene evolution. Six mature leaves from the upper part of the canopy were randomly collected from the trees of each leaf WP treatment. Five samples with two leaf disks each were used to measure ethylene evolution. Ion leakage was measured from flower buds and leaf disks that were used for ethylene determination.

Gibberellic acid (Expt. II). On 6 Jan. 1990, four lateral branches were selected on each of 10 coffee trees growing in the greenhouse. On each branch, aqueous solutions of $\mathrm{O}, 50,100$, or 200 $\mathrm{mg} \mathrm{GA}_{3}$ /liter (Sigma, St. Louis; dissolved in ethanol, then diluted with distilled water) plus $0.2 \%$ Tween 20 (US Biochemical Corp., Cleveland) were applied with a brush to buds, foliage, and stems. Control branches were painted with solutions containing ethanol, Tween 20, and distilled water. Trees were irrigated daily with $500 \mathrm{ml}$ of water. Ethylene evolution of two flower buds from treated branches on each tree was determined every 5 days until 20 days after $\mathrm{GA}_{3}$ application (26 Jan. 1990). The number of open flowers per node and percentage of nodes at anthesis on five preselected nodes per treatment on each tree were recorded. The data were analyzed as a randomized complete-block design with one tree representing a block.

WP and gibberellic acid (Expt. III). Water was witheld from 4 Dec. 1989 until the leaf WP of three trees each averaged $-0.6,-1.3,-2.1$, or $-3.0 \mathrm{MPa}$. At rewatering (day O), aquaeous solutions, prepared as in Expt. II, of 0, 50, and 100 $\mathrm{mg} \mathrm{GA}_{3} /$ liter were applied with a brush to buds, foliage, and stems of individual lateral branches. The experiment was a splitplot design with water stress as the main plot applied to three trees each, and each $\mathrm{GA}_{3}$ concentration applied to two branches per tree as the subplot. On each tree, five preselected nodes per $\mathrm{GA}_{3}$ treatment were monitored for anthesis and flower bud length. Leaf WP, and ethylene production and ion leakage of flower buds and leaf disks were determined on day 0 before irrigation of water-stressed trees, and 3, 6, and 9 days after rewatering. Sampling procedures and number of samples were the same for each leaf $\mathrm{WP} / \mathrm{GA}_{3}$ treatment combination as for each leaf WP treatment in Expt. I.

WP measurements. On each sampling date, leaf xylem WP of the two most recently fully expanded leaves on a lateral branch in the upper half of the canopy was measured with a pressure chamber (PMS, Corvallis, Ore.) for each tree. Leaf and flower bud samples were taken between 1 and $3 \mathrm{~h}$ after the onset of the photoperiod in the growth chambers. Water potential of flower buds was measured with a thermocouple psychrometer (Decagon Devices, Pullman, Wash.) Flower buds were cut at the base of the pedicel, and two buds were equilibrated in thermocouple cups for $2 \mathrm{~h}$ before the measurements were taken. The psychrometer was calibrated with two or three standard $\mathrm{KCl}$ solutions at each sampling time.

Ethylene measurements. For each sample, two flower buds or two 10-mm leaf disks were incubated with a drop of water in 5-ml syringes for $2 \mathrm{~h}$ in the dark at room temperature (22 to 24C). A 1.0-ml gas sample was injected in a Gow-Mac Series 580 (Gow-Mac Instrument, Bridgewater, N.J.) gas chromatography with a flame ionization detector and activated alumina column. Column, detector, and injector temperatures were 80 , 100, and 90C, respectively. Flow rates for helium and hydrogen were $25 \mathrm{ml} \cdot \mathrm{min}^{-1}$ and $200 \mathrm{ml} \cdot \mathrm{min}^{-1}$ for air.

Ion leakage. Flower buds and leaf disks used for ethylene determination were incubated in stoppered vials with $3 \mathrm{ml}$ of double-distilled water, placed on a shaker for $24 \mathrm{~h}$, and initial ion leakage was measured with a conductivity meter (Electromark Analyzer, Markson Sci., Phoenix, Ariz.). The final leakage was determined after vials were placed in a $60 \mathrm{C}$ waterbath for $2 \mathrm{~h}$ to kill the plant tissue, and incubated for another $24 \mathrm{~h}$ on the shaker. Percent leakage was calculated as the ratio of initial : final values $\times 100$.

\section{Results}

WP. Plants that attained leaf xylem WP of -2.65 and -3.5 $\mathrm{MPa}$ reached anthesis within 9 days after irrigation, whereas those exposed to - 1.2 and -1.75 MPa leaf WP did not flower (Fig. 1). Flower buds that developed to anthesis $(-2.65$ and $-3.5 \mathrm{MPa}$ leaf WP treatments) had a WP of about $-4.0 \mathrm{MPa}$ before plants were irrigated (Fig. 1). Three days after irrigation, all treatments had equilibrated to flower-bud WP of $-2.5(\& 0.2)$ $\mathrm{MPa}$, and thereafter WP ranged between - 1.8 and - 2.7 MPa. Leaf WP of all trees ranged between -0.6 and $-1.1 \mathrm{MPa} 3$, 6 , and 9 days after irrigation.

Flower buds from plants that were stressed to leaf WP of -2.65 and $-3.5 \mathrm{MPa}$ and developed to anthesis produced significantly $(P=0.01)$ less ethylene at 0,3 , and 6 days after irrigation than buds from plants exposed to less severe water stress (Fig. 2). Ethylene evolution of flower buds did not differ between treatments 9 days after irrigation. Leaf disks from plants that were stressed to -2.65 and $-3.5 \mathrm{MPa}$ produced more ethylene 3 and 6 days after irrigation than disks from plants stressed to -1.2 and $-1.75 \mathrm{MPa}$ (Table 1).

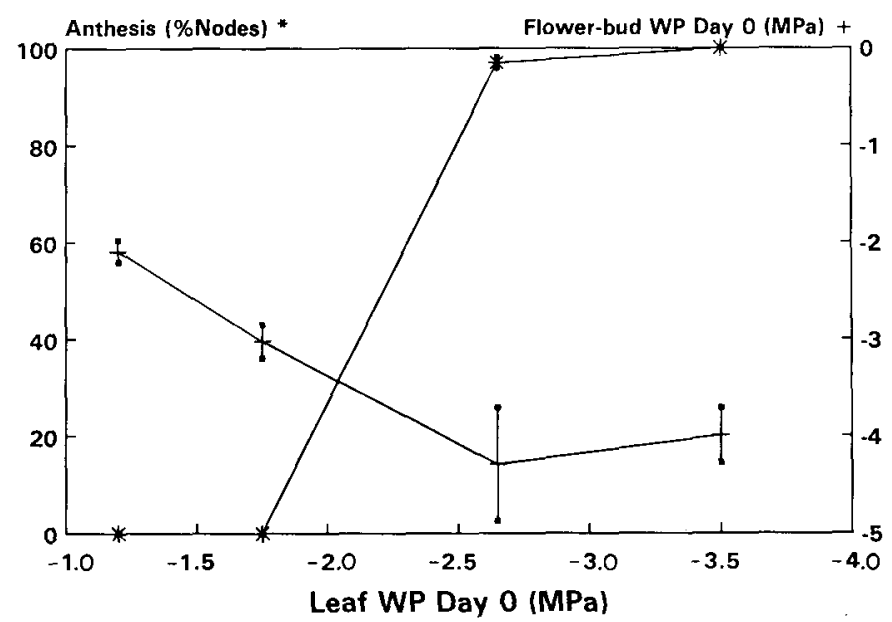

Fig. 1. Relationship between leaf xylem WP at day 0 and anthesis at day 9 and flower-bud WP at day 0 (Expt. I). Leaf and flower-bud WP were measured immediately before irrigation of water-stressed plants. Flowering occurred 9 days after irrigation. Vertical bars represent \pm SE. 


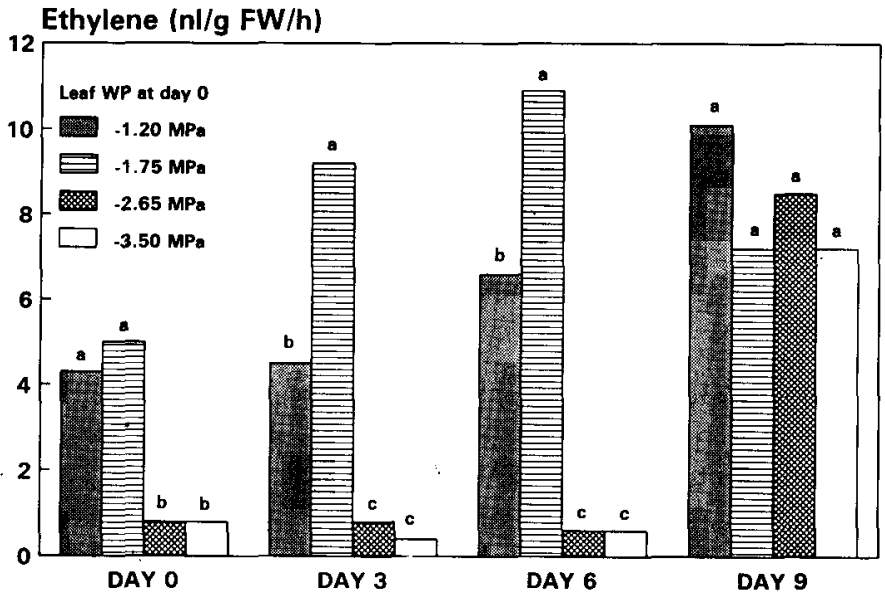

Fig.2. Effect of water stress on ethylene evolution from flower buds $0,3,6$, and 9 days after irrigating-to release water stress (Expt. I). Each mean represents five replications. Columns with different letters within a sampling date indicate significant differences between treatments at $P=0.05$, Tukey's studentized range test.

Table 1. Ethylene evolution of leaf disks from trees that were water stressed (Expt. I).

\begin{tabular}{ccccc}
\hline & \multicolumn{4}{c}{$\begin{array}{c}\text { Ethylene evolution } \\
\text { (nl/g fresh wt per hour) }\end{array}$} \\
\cline { 2 - 5 } Leaf WPz & \multicolumn{4}{c}{ Days after treatment } \\
$(\mathrm{MPa})$ & 0 & 3 & 6 & 9 \\
\hline-1.20 & $0.8 \mathrm{ab}^{y}$ & $0.6 \mathrm{a}$ & $0.8 \mathrm{a}$ & $0.8 \mathrm{a}$ \\
-1.75 & $0.5 \mathrm{a}$ & $0.6 \mathrm{a}$ & $0.7 \mathrm{a}$ & $1.0 \mathrm{a}$ \\
-2.65 & $1.1 \mathrm{ab}$ & $1.6 \mathrm{~b}$ & $1.3 \mathrm{~b}$ & $0.8 \mathrm{a}$ \\
-3.50 & $1.6 \mathrm{~b}$ & $1.3 \mathrm{~b}$ & $1.3 \mathrm{~b}$ & $2.3 \mathrm{~b}$ \\
\hline
\end{tabular}

${ }^{2} \mathrm{WP}$ is leaf water potential at day 0 , immediately before trees were irrigated.

'Means within a column followed by different letters indicate significant differences between treatments at $P=0.05$, Tukey's studentized range test.

Table 2. Ion leakage of flower buds and leaf disks from water-stressed trees (Expt. I).

\begin{tabular}{lcccc}
\hline & \multicolumn{5}{c}{ Ion leakage (\%) } \\
\cline { 2 - 5 } $\begin{array}{l}\text { Leaf WP } \\
\text { (MPa) }\end{array}$ & \multicolumn{5}{c}{ Days after treatment } \\
\cline { 2 - 5 } & 0 & 3 & 6 \\
-1.20 & $7.0 \mathrm{a}^{\mathrm{y}}$ & $5.4 \mathrm{a}$ & $7.0 \mathrm{a}$ & $4.9 \mathrm{a}$ \\
-1.75 & $5.1 \mathrm{a}$ & $3.1 \mathrm{a}$ & $5.8 \mathrm{a}$ & $5.0 \mathrm{a}$ \\
-2.65 & $6.2 \mathrm{a}$ & $10.3 \mathrm{~b}$ & $8.3 \mathrm{a}$ & $39.1 \mathrm{~b}$ \\
-3.50 & $10.5 \mathrm{a}$ & $4.7 \mathrm{a}$ & $21.9 \mathrm{~b}$ & $53.6 \mathrm{c}$ \\
& \multicolumn{4}{c}{ Leaf disks } \\
-1.20 & $5.2 \mathrm{a}$ & $7.4 \mathrm{~b}$ & $10.5 \mathrm{~b}$ & $5.8 \mathrm{a}$ \\
-1.75 & $6.3 \mathrm{a}$ & $5.7 \mathrm{a}$ & $8.8 \mathrm{ab}$ & $9.4 \mathrm{~b}$ \\
-2.65 & $7.1 \mathrm{a}$ & $8.3 \mathrm{~b}$ & $8.4 \mathrm{ab}$ & $7.8 \mathrm{ab}$ \\
-3.50 & $10.4 \mathrm{~b}$ & $5.2 \mathrm{a}$ & $7.6 \mathrm{a}$ & $8.8 \mathrm{~b}$ \\
\hline
\end{tabular}

${ }^{2}$ Water potential at day 0 , immediately before trees were irrigated. ${ }^{y}$ Means within a column followed by different letters indicate significant differences between treatments at $P=0.05$, Tukey's studentized range test.

Ion leakage of flower buds and leaf disks was generally higher in plants exposed to greater water stress, but the effect was not consistent (Table 2). Flower buds exhibited the highest amount of ion leakage at anthesis. Ion leakage ranged between 3\% and $10 \%$ for leaf disks and flower buds at all other sampling times.
Gibberellic acid. Branches treated with $200 \mathrm{mg} \mathrm{GA}_{3} /$ liter had the most flowers per node that had reached anthesis 10 days after treatment (Table 3). The percentage of nodes with flowers at anthesis varied considerably between trees (Table 3). Abnormal flower buds occurred in all treatments, either as safflowers (van der Veen, 1968) that opened when buds were still $\leq 4 \mathrm{~mm}$ long, or 4-mm buds remained closed with the style elongating beyond the petals (Cambrony and Snoeck, 1983; Huxley and Ismail, 1969). In either case, flowers aborted within 2 weeks after opening or style elongation. Styles of flowers treated with the highest $\mathrm{GA}_{3}$ concentration elongated to 8 to $12 \mathrm{~mm}$, whereas styles were shorter using lower $\mathrm{GA}_{3}$ concentrations.

Gibberellic acid did not influence ethylene production (nanoliters per gram fresh weight per hour) of flower buds, except 15 days after irrigation $(P=0.01)$, when buds treated with 100 or $200 \mathrm{mg}$. GA $/$ liter evolved 6.6 and $7.8 \mathrm{nl} / \mathrm{g}$ fresh weight per $\mathrm{h}$; those treated with 0 or $50 \mathrm{mg} \mathrm{GA}_{3} /$ liter-poduced 5.1 and $5.3 \mathrm{nl} / \mathrm{g}$ fresh weight per h, respectively. Ethylene evolution of flower buds ranged from 4.4 to $7.8 \mathrm{nl} / \mathrm{g}$ fresh weight per $\mathrm{h}$ for all samples.

WP and gibberellic acid. Plants stressed to leaf WP of -3.0 $\mathrm{MPa}$ flowered within 8 days after irrigation, regardless of the $\mathrm{GA}_{3}$ treatment (Table 4). Anthesis was delayed on a small percentage of nodes from plants stressed to leaf WP of -2.1 MPa or less (Table 4).

Flower buds of plants that were stressed to - 3.0 MPa produced $(P=0.01)$ less ethylene 0,3 , and 6 days after irrigation, and more ethylene 9 days after irrigation than flower buds of plants that were exposed to leaf xylem WP of $-2.1,-1.2$, or - 0.6 MPa (Fig. 3). Because $\mathrm{GA}_{3}$ treatment did not influence

Table 3. Anthesis of coffee flower buds 10 days after treatment with GA, (Expt. II).

\begin{tabular}{|c|c|c|}
\hline $\begin{array}{c}\mathrm{GA}_{3} \\
\left(\mathrm{mg} \cdot \mathrm{liter}^{-1}\right)\end{array}$ & $\begin{array}{c}\text { Flowers/node } \\
\text { at anthesis }\end{array}$ & $\begin{array}{c}\text { Flowering nodes } \\
(\%)\end{array}$ \\
\hline $\begin{array}{r}0 \\
50 \\
100 \\
200\end{array}$ & $\begin{array}{l}1.0^{\mathrm{z}} \\
1.4^{\mathrm{NS}} \\
0.9^{\mathrm{NS}} \\
2.6^{*}\end{array}$ & $\begin{array}{ll}34 & (8.4)^{y} \\
40 & (9.6) \\
36 & (7.5) \\
64 & (14.8)\end{array}$ \\
\hline
\end{tabular}

${ }^{2}$ Means within a column followed by $*$ or Ns indicate significant or no significant difference at $P=0.05$, respectively, between control and $\mathrm{GA}_{3}$ treatments (Dunnett's Test).

${ }^{y}$ Mean (standard error).

Table 4. Percentage of nodes with flowers at anthesis 8 and 28 days after plants at different leaf xylem water potentials (WP) were treated with $\mathrm{GA}_{3}$ Expt. III).

\begin{tabular}{lccc}
\hline \hline \multirow{2}{*}{$\begin{array}{c}\mathrm{WP} \\
(\mathrm{MPa})\end{array}$} & $\begin{array}{c}\mathrm{GA}_{3} \\
\left(\mathrm{mg} \cdot \text { liter }^{-1}\right)\end{array}$ & \multicolumn{2}{c}{ Flowering nodes $(\%)^{\mathbf{z}}$ after } \\
\cline { 2 - 4 }-0.6 & 0 & 0 & 28 days \\
& 50 & 0 & $10.0(5.8)$ \\
& 100 & 0 & $26.7(17.7)$ \\
-1.3 & 0 & 0 & $30.0(19.8)$ \\
& 50 & 0 & 0 \\
& 100 & 0 & 0 \\
-2.1 & 0 & 0 & $10.0(9.9)$ \\
& 50 & $10.0(5.8)$ & 0 \\
-3.0 & 100 & $23.3(14.5)$ & 0 \\
& 0 & $93.3(6.7)$ & 0 \\
& 50 & $96.7(3.3)$ & 0 \\
\hline \hline
\end{tabular}

${ }^{2}$ Each mean (standard error) is calculated from 30 nodes (10 nodes replicated on three trees). 


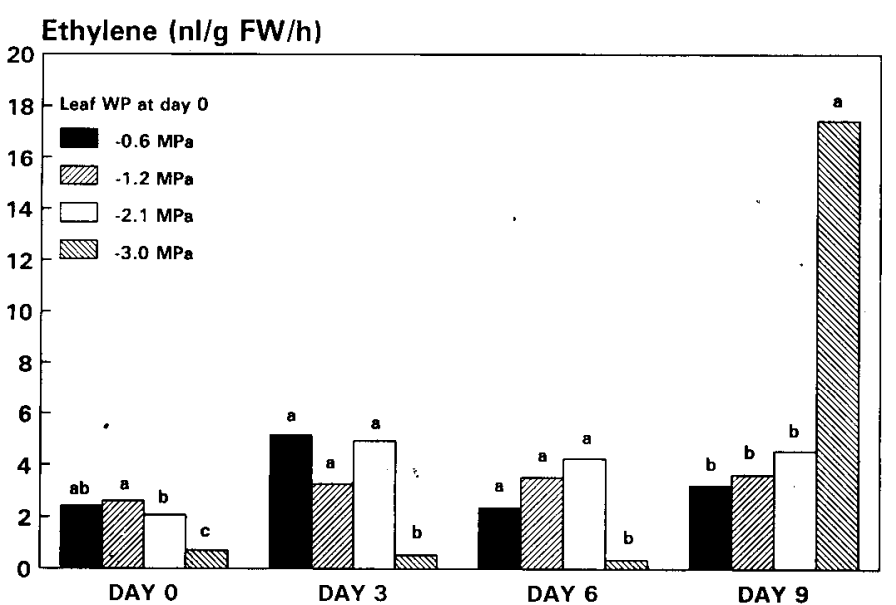

Fig. 3. Effect of water stress and $\mathrm{GA}_{3}$ on ethylene evolution of flower buds $\mathrm{O}, 3,6$, and 9 days after irrigating to release water stress (Expt. III). Means are pooled over GA, treatments $\left(0,50,100 \mathrm{mg} \cdot\right.$ liter- $\left.^{-1}\right)$, each bar represents 20 replications. Columns with different letters within a sampling date indicate significant differences between treatments at $P=0.05$, Tukey's studentized range test.

Table 5. Ethylene evolution from leaf disks from coffee trees that were water stressed and received $\mathrm{GA}_{3}$ treatments (Expt. 111).

\begin{tabular}{|c|c|c|c|c|}
\hline \multirow{3}{*}{$\begin{array}{l}\text { Leaf } \mathrm{WP}^{z} \\
(\mathrm{MPa})\end{array}$} & \multicolumn{4}{|c|}{$\begin{array}{l}\text { Ethylene evolution } \\
\text { (n1/g fresh wt per hour) }\end{array}$} \\
\hline & \multicolumn{4}{|c|}{ Days after treatment } \\
\hline & 0 & 3 & 6 & 9 \\
\hline-0.6 & $1.0^{\mathrm{x}} \mathrm{a}$ & $0.7 \mathrm{a}$ & $1.0 \mathrm{a}$ & $0.6 \mathrm{ab}$ \\
\hline-1.2 & $0.4 \mathrm{~b}$ & $1.9 \mathrm{~b}$ & $0.8 \mathrm{a}$ & $0.5 \mathrm{a}$ \\
\hline-2.1 & $0.7 \mathrm{ab}$ & $1.1 \mathrm{ab}$ & $1.1 \mathrm{a}$ & $0.7 \mathrm{ab}$ \\
\hline-3.0 & $0.9 \mathrm{a}$ & $1.5 \mathrm{ab}$ & $1.2 \mathrm{a}$ & $0.9 \mathrm{~b}$ \\
\hline \multicolumn{5}{|c|}{ GA, (mg.liter- $\left.{ }^{1}\right)$} \\
\hline 0 & 1.0 & $0.9^{\mathrm{w}}$ & 0.6 & 0.5 \\
\hline 50 & -- & $1.2^{\mathrm{NS}}$ & $1.1^{\mathrm{NS}}$ & $0.7^{\mathrm{NS}}$ \\
\hline 100 & --- & $1.8^{*}$ & $1.3 *$ & $0.8^{*}$ \\
\hline
\end{tabular}

${ }^{2}$ Water potential at day 0 , immediately before trees were irrigated and $\mathrm{GA}_{3}$ was applied.

${ }^{y}$ Means are pooled by main effects and represent 15 and 20 replications for WP and $\mathrm{GA}_{3}$, respectively.

${ }^{x}$ Means within a column followed by different letters indicate significant differences between treatments at $P=0.05$, Tukey's studentized range test.

"Means within a column followed by * or NS indicate significant or no significant difference at $P=0.05$, respectively, between control and $\mathrm{GA}_{3}$ treatments (Dunnett's test).

ethylene production of flower buds except on the day of anthesis, the data were pooled, and no interaction was observed on day 0,3 , and 6 (Fig. 3). On day 9 there was a significant $(\mathrm{P}=0.05)$ interaction between WP and GA, treatment affecting ethylene evolution.

Ethylene evolution of leaf disks was significantly $(P=0.05)$ influenced by WP 0,3 , and 9 days after irrigation, and by $\mathrm{GA}_{3}$ treatment 3, 6, and 9 days after treatment (Table 5). No significant. interactions were found at any sampling time. Ethylene evolution of leaf disks treated with $100 \mathrm{mg}$ GA3/liter was always higher than that of the control, but the difference decreased over time (Table 5).

Ion leakage of flower buds and leaf disks was significantly $(\mathrm{P}=0.05)$ affected by water stress treatments at all sampling times (Table 6). Because $\mathrm{GA}_{3}$ had no effect on ethylene evolution of flower buds, the data were pooled for all $\mathrm{GA}_{3}$ treat-
Table 6. Ion leakage of flower buds and leaf disks from coffee trees following water stress and $\mathrm{GA}_{3}$ treatments (Expt. III).

\begin{tabular}{|c|c|c|c|c|}
\hline \multirow{3}{*}{$\begin{array}{c}\text { Leaf WPz } \\
(\mathrm{MPa})\end{array}$} & \multicolumn{4}{|c|}{ Ion leakage $(\%)$} \\
\hline & \multicolumn{4}{|c|}{ Days after treatment } \\
\hline & 0 & 3 & 6 & 9 \\
\hline & \multicolumn{4}{|c|}{ Flower buds } \\
\hline-0.6 & $6.6 a^{y, x}$ & $6.9 \mathrm{a}$ & $5.8 \mathrm{a}$ & $4.9 \mathrm{a}$ \\
\hline-1.2 & $4.8 \mathrm{a}$ & $7.4 \mathrm{a}$ & $8.7 \mathrm{ab}$ & $4.6 \mathrm{a}$ \\
\hline-2.1 & $9.8 \mathrm{~b}$ & $6.0 \mathrm{a}$ & $8.8 \mathrm{ab}$ & $16.8 \mathrm{~b}$ \\
\hline \multirow[t]{2}{*}{-3.0} & $11.3 \mathrm{~b}$ & $10.4 \mathrm{~b}$ & $10.2 \mathrm{~b}$ & $57.9 \mathrm{c}$ \\
\hline & \multicolumn{4}{|c|}{ Leaf disks } \\
\hline-0.6 & $8.8 \mathrm{a}^{\mathrm{w}}$ & $6.3 \mathrm{a}$ & $9.8 \mathrm{bc}$ & $8.6 \mathrm{ab}$ \\
\hline-1.2 & $5.6 \mathrm{a}$ & $7.9 \mathrm{ab}$ & $11.1 \mathrm{c}$ & $7.7 \mathrm{ab}$ \\
\hline-2.1 & $8.0 \mathrm{a}$ & $7.4 a b$ & $8.6 \mathrm{bc}$ & $7.2 \mathrm{a}$ \\
\hline-3.0 & $14.3 \mathrm{~b}$ & $8.6 \mathrm{~b}$ & $7.5 \mathrm{a}$ & $9.0 \mathrm{~b}$ \\
\hline $\mathrm{GA}_{3}\left(\mathrm{mg} \cdot \mathrm{liter}^{-1}\right)$ & & & & \\
\hline 0 & 9.2 & $7.6^{v}$ & 8.5 & 7.4 \\
\hline 50 & -- & $7.3^{\mathrm{NS}}$ & $9.0^{\mathrm{NS}}$ & $8.3^{\mathrm{NS}}$ \\
\hline 100 & -- & $7.8^{\mathrm{NS}}$ & $10.3^{*}$ & $8.7^{*}$ \\
\hline
\end{tabular}

${ }^{2}$ Water potential at day 0 , immediately before trees were irrigated and $\mathrm{GA}_{3}$ was applied.

${ }^{y}$ Means are pooled for $\mathrm{GA}_{3}$ and represent 20 replications.

${ }^{x}$ Means within a column followed by different letters indicate significant differences between treatments at $P=0.05$, Tukey's studentized range test.

"Means represent 20 and 15 replications for $\mathrm{GA}_{3}$ and leaf WP treatment, respectively.

"Means within a column followed by * or Ns indicate significant or no significant difference at $P=0.05$, respectively, between control and $\mathrm{GA}_{3}$ treatments (Dunnett's test).

ments. Ion leakage of flower buds at day $\mathrm{O}$ was about twice as high for the -2.1 and $-3.0 \mathrm{MPa}$ treatments as for the lower water stress treatments (Table 6), and buds from these treatments had the highest ion leakage at anthesis, 9 days after irrigation (Table 6).

In leaf disks from - 3.0 MPa-stressed plants, almost twice the percentage of ion leakage occurred as in those from other treatments (Table 6) at day 0. The main effects of leaf WP and $\mathrm{GA}_{3}$ treatment on ion leakage of leaf disks are shown, because of a significant $(\mathrm{P}=0.05)$ interaction between leaf WP and $\mathrm{GA}_{3} 6$ days after irrigation.

When plants were exposed to water stress, flower buds were between 4 and $6 \mathrm{~mm}$ long. Three days after irrigation to release water stress, flower buds that developed subsequently to anthesis had expanded to 9 to $12 \mathrm{~mm}$, and doubled this length within the next 3 days. Flower buds were up to $25 \mathrm{~mm}$ long before anthesis. Flower buds treated with $\mathrm{GA}_{3}$ tended to expand slightly faster than untreated ones, but differences were not statistically significant. Flower buds that remained dormant did not elongate.

\section{Discussion}

Studies on coffee flowering have shown that water stress is required for flower buds to break dormancy and develop to anthesis. Flowering observed 8 to 10 days after irrigation of stressed plants indicated that flower bud dormancy had been broken by water stress (Alvim, 1960; Piringer and Borthwick, 1955; van der Veen, 1968). However, unlike Magalhaes and Angelocci (1976), who reported a minimum threshold leaf WP of - 1.2 MPa and flower-bud WP of - 1.4 MPa to break dormancy, greater water stress was needed in our Expts. I and III (Fig. 1, Table 4). Under a daily watering regime, leaf WP were 
between -0.6 and $-1.1 \mathrm{MPa}$ in unstressed trees or in trees that were irrigated to release water stress, whereas the -1.2 MPa leaf WP reported by Magalhaes and Angelococci (1976) was sufficient to break dormancy in their coffee flower buds. This difference might be due to the time of sampling, position of sampling, plant cultivar, and plant age.

Some plants stressed to a leaf WP of - 2.1 MPa flowered partially 8 days after rewatering, but only when treated with $\mathrm{GA}_{3}$ (Table 4). It appears that $\mathrm{GA}_{3}$, in combination with mild water stress, can stimulate anthesis, possibly by compensating for low endogenous GA. These results agree with Alvim's (1958) observations that $\mathrm{GA}_{3}$ was more effective in breaking dormancy in water-stressed than in unstressed coffee plants, and that $\mathrm{GA}_{3}$ application during the rainy season did not affect flowering. Browning (1973) suggested that a rise in endogenous GA content is the stimulus for releasing dormant coffee flower buds. He showed that after bud dormancy was broken with water stress and regrowth stimulated by irrigation or rain, the endogenous GA concentration in flower buds increased significantly before buds gained fresh weight. Since GA biosynthesis inhibitors did not prevent dormancy release, he suggested that GA is converted from a bound form to a free, active form at the time of release from dormancy. We found that a GA biosynthesis inhibitor (paclobutrazol, applied before water stress as a soil drench in $500 \mathrm{ml}$ of water at concentrations of $\mathrm{O}, 5,50$, and $100 \mathrm{mg} / \mathrm{pot}$ ) did not inhibit flowering after plants were released from dormancy (data not shown).

Differences in transpiration and soil moisture content between plants result in different levels of water stress and can lead to varying dormancy status and different responsiveness to GA in flower buds. Factors that favor release from dormancy might accumulate, similar to chilling accumulation observed in dormant plants in temperate zones (Alvim, 1960). Flowering in Expt. II (Table 3) and the uncharacteristic flowering 28 days after release from water stress in Expt. III (Table 4) might be the result of different dormancy status of flower buds at the beginning of the two experiments. Gibberellic acid might provide the required stimulus for continued bud development after water stress or compensate for water stress that is inadequate for breaking dormancy, as indicated by increased blossoming with higher GA concentrations in less stressed trees (Table 4).

Ethylene evolution of dormant flower buds was always higher than in buds in which dormancy had been broken by water stress (Figs. 2 and 3). The severe water stress required to remove dormancy did not increase ethylene production, an unexpected result, since ethylene evolution generally increases in stressed tissues (Abeles, 1973). In contrast to coffee flower buds, tight orchid (Arachnis hookerana $\times$ Vanda 'Hilo Blue') buds produce relatively high concentrations of ethylene throughout their development (Yip and Hew, 1988). The physiological stage of flower buds determines ethylene evolution, which was found to vary considerably between orchid genera (Gob et al., 1985). We observed increased ethylene production at anthesis, which may be due to pollination, as reported by Reid (1988). The difference in, ethylene production by dormant and nondormant coffee flower buds is an important finding that allows separation of physiological stages that cannot be distinguished by morphology or anatomy.

Throughout the experiment, ethylene evolution of leaf disks (Tables 1 and 5) was highest from severely water-stressed plants. Similarly, Kobayashi et al. (1981) showed that ethylene production increased in water-stressed plum leaves as moisture loss increased. The general pattern of increasing ethylene production by tissues under stress was confirmed in this study for leaf disks from coffee plants, but the opposite was found for flower buds.

The most severely water-stressed plants showed the highest amount of ion leakage from flower buds and leaf disks at the end of the water stress treatment, but before irrigation was applied (Tables 2 and 6). An increase in ion leakage was found in severely dehydrated plum leaves, when $\geq 50 \%$ moisture was lost (Kobayashi et al., 1981). Similar observations were made in tissues that were damaged by freezing stress (Harber and Fuchigami, 1986). Fluctuating values for flower-bud and leaf tissue indicate that the increase in ion leakage was temporary, and that the initial high values for severely stressed tissue caused no permanent damage to membrane permeability or cell death. In flower buds that continued to develop to anthesis, ion leakage increased as buds grew rapidly. Increased ion leakage of flower buds and leaf disks was related to severe stress before waterstressed plants were irrigated. Unlike ethylene evolution, ion leakage of flower buds was not related to the dormancy status.

These experiments show that threshold leaf and bud WP were necessary to break dormancy in coffee flower buds. In flower buds, where dormancy was not completely broken by water stress, $\mathrm{GA}_{3}$ stimulated development to anthesis, possibly by compensating for a lack of endogenous GA. Ethylene evolution was found to be useful in distinguishing between dormant and nondormant flower buds.

\section{Literature Cited}

Abeles, F.B. 1973. Ethylene in plant biology. Academic, New York. Alvim, P. de T. 1958. Estimulo de la floración y fructificación del café por aspersions con ácido giberélico. Turrialba 8(2):64-72.

Alvim, P. de T. 1960. Moisture stress as a requirement for flowering of coffee. Science 132:354.

Astegiano, E. D., M. Maestri, and M. de M. Estevao. 1988. Water stress and dormancy release in flower buds of Coffea arabica L.: Water movement into the buds. J. Hort. Sci. 63:529-533.

Browning, G. 1973. Flower bud dormancy in Coffea arabica L. I. Studies of gibberellin in flower buds and xylem sap and of abscisic acid in flower buds in relation to dormancy release. J. Hort. Sci. 48:29-41.

Browning, G. 1975. Environmental control of flower bud dormancy in Cofea arabica L, p. 321-336. In: J.J. Landsberg and C.V. Cutting (eds.). Environmental effects on crop physiology. Academic, London.

Cambrony, H.R. and J. Snoeck. 1983. Hormones et regulateurs de croissance clans les cultures de caféiers et de cacoyers. Café Cacao Thé 27(2):113-120.

Cannell, M.G.R. 1985. Physiology of the coffee crop, p. 108-134. In: M.N. Clifford and K.C. Willson (eds.). Coffee botany, biochemistry and production of beans and beverage. Croom Helm, New York.

Fuchigami, L.H. and C.C. Nee. 1987. Degree growth stage model and rest-breaking mechanisms in temperate woody perennials. HortScience 22:836-845.

Gob, C.J., A.H. Halevy, R. Engel, and A.M. Kofranek. 1985. Ethylene evolution and sensitivity in cut orchid flowers. Scientia Hort. 26:57-67.

Harber, R.M. and L.H. Fuchigami. 1986. The relationship of ethylene and ethane production to tissue damage in frozen rhododendron leaf disks. J. Amer. Soc. Hort. Sci. 111:434-436.

Huxley, P.A. and S.A.H. Ismail. 1969. Floral atrophy and fruit set in Arabica coffee in Kenya. Turrialba 19:345-354.

Kobayashi, K., L.H. Fuchigami, and K.E. Brainerd. 1981. Ethylene and ethane production and electrolyte leakage of water-stressed 'Pixy' plum leaves. HortScience 16:57-59.

Magalhaes, A.C. and L.R. Angelocci. 1976. Sudden alterations in 
water balance associated with flower bud opening in coffee plants. J. Hort. Sci. 51:419-123.

Mes, M.G. 1957. Studies on flowering of Coffea arabica L. IBEC Res. Inst., Bul. 14, New York.

Nee, C.C. 1986. Overcoming bud dormancy with hydrogen cyanamide: Timing and mechanism. PhD Diss., Oregon State Univ., Corvallis.

Piringer, A.A. and H.A. Borthwick. 1955. Photoperiodic responses of coffee. Turrialba 5:72-77.

Reid, M.S. 1988. Ethylene in plant growth, development, and senes- cence, p. 257-279. In: P.J. Davies (cd.). Plant hormones and their role in plant growth and development. Kluwer Academic Publ. Dordrecht.

Schuch, U.K., L.H. Fuchigami, and M.A. Nagao. 1990. Gibberellic acid causes earlier flowering and synchronizes fruit ripening of coffee. J. Plant Growth Regulat. 9:59-64.

van der Veen, V.D. 1968. Plant hormones and flowering in coffee. Acts Bet. Neerl. 17:373-376.

Yip, K.C. and C.S. Hew. 1988. Ethylene production by young Aranda orchid flowers and buds. J. Plant Growth Regulat. 7:217-222. 